International Journal of Public Finance
E-ISSN: $2548-0499 \quad$ DOI: $10.30927 /$ ijpf.335594
Vol./Cilt: 2 | Issue/Sayı: 2 | (2017), pp. $159-175$
journal homepage: http://dergipark.gov.tr/ijpf

\title{
Fiscal Drag as an Automatıc Stabılıty Tool, in The Case of New Regulation with Price Criteria in Automotive Sectors Special Consumption Tax (SCT)
}

\author{
Abdurrahman TARAKTAŞ ${ }^{1}$ \\ Canatay HACIKÖYLÜ²
}

\begin{tabular}{|c|c|}
\hline ARTICLE INFO & B S T R A C T \\
\hline $\begin{array}{l}\text { Received: } 11.09 .2017 \\
\text { Received in revised } \\
\text { form: } 29.11 .2017 \\
\text { Accepted: } 12.12 .2017 \\
\text { Available online: } \\
\text { 05.01.2018 }\end{array}$ & $\begin{array}{l}\text { Fiscal drag is a result of real or nominal expanding economy and progressive } \\
\text { taxation. In general, individuals are forced to enter the upper tax bracket } \\
\text { depending on their increased income or expenditure. More tax burden can } \\
\text { result in less consumption. Fiscal drag, lack of spending or excessive } \\
\text { taxation can cause the economy to slow down. Traditional view suggests } \\
\text { that fiscal drag may serve as a natural automatic stabilizer to cool the }\end{array}$ \\
\hline $\begin{array}{l}\text { JEL classification: } \\
\mathrm{H} 21, \mathrm{H} 23, \mathrm{H} 26\end{array}$ & $\begin{array}{l}\text { economy. However, this view ignores the supply side and in particular the } \\
\text { potential effects of the high tax burden on the economy. } \\
\text { This study examines the extent to which the expected automatic }\end{array}$ \\
\hline $\begin{array}{l}\text { Keywords: } \\
\text { Fiscal Drag, Excessive } \\
\text { Taxation, Automotive } \\
\text { Sectors, Special } \\
\text { Consumption Tax }\end{array}$ & $\begin{array}{l}\text { stabilization function can be performed and the possible side effects on } \\
\text { economic balances and income distribution of fiscal drag in our country in } \\
\text { the case of new regulation with price criteria in automotive sectors Special } \\
\text { Consumption Tax (SCT). }\end{array}$ \\
\hline
\end{tabular}

\section{Introduction}

Fiscal drag is emerging as an impact of inflation on the tax rates. If the thresholds or tax exemptions and deductions in the tax tariffs are not updated according to the inflation, it causes the taxpayers to go to the upper tax thresholds and increase their tax burden. This process is automatic and does not require any political decision. This is called nominal fiscal drag, if the nominal earnings of the taxpayers decrease with increasing tax burden but there is no decrease in real earnings due to fiscal drag. If the fiscal drag also creates a reduction in the taxpayer's real gains, then the real fiscal drag has come to the fore. There is also an increase in the share of the

\footnotetext{
${ }^{1}$ Assist. Prof. PhD, Anadolu University Faculty of Economics and Administrative Sciences, Public Finance Department, ataraktas@anadolu.edu.tr

2 Assist. Prof. PhD, Anadolu University Faculty of Economics and Administrative Sciences, Public Finance Department, chacikoylu@anadolu.edu.tr
} 
government in the gross national product with real nominal fiscal drag. At the same time, fiscal drag can also lead to the unjust distribution of the tax burden.

Especially the tax liabilities related to motor vehicles are important in Turkey both in terms of administration and taxpayers and they direct the practices of the parties from the formation of tax policies to consumer behavior. In the most general sense, the taxes from motor vehicles is a good example to the use of the whole range of consumption taxes (Hacıköylü, 2017: 83).

The present study aims to illustrate the effects of fiscal drag, which is widely regarded as an automatic stabilizer by policy makers, in the context of the last regulation on automobiles in Special Consumption Tax in Turkey. Section 2 reviews the concept of fiscal drag as an automatic stabilizer and thus providing the theoretical background necessary to facilitate the analysis of changes in the legislation in Turkey. Section 3 describes the main structure and functioning of the Special Consumption Tax, and puts forward its legal and fiscal importance within the Turkish tax system. Section 4 reveals how the recent regulations in the Special Consumption Tax could lead to fiscal drag, and some of the deficiencies ignored in the regulation. As a conclusion, evaluations were made to highlight the way for policymakers and future studies.

\section{Fiscal Drag as an Automatic Stability Tool}

Automatic stabilizers are generally associated with the cyclical nature of taxes, transfers and public expenditures. Automatic stabilizers are economic policies and programs designed to balance fluctuations in disposable income, and therefore in consumption, of imbalances stemming from business cycles, without the individual intervention of policy makers. The issue that automatic stabilizers can contribute to the general instability of the economy is not much discussed. Automatic stabilizers can lead to the expansion of the public sector's share in the economy. While the growth of the public sector, which has a stable spending structure, will reduce the fluctuations in the economy, should generate long-term negative effects on the general level of prices and employment markets (Fatas and Mihov, 2001: 5-6).

In 1960, the concept of fiscal drag began to come to the fore. There was an emphasis on official reports as an important means of automatic stabilization.

According to Council of Economic Advisers (1969: 72) "By prewar standards, 1948 and 1961 recessions were all relatively short and mild, though nevertheless costly. They were limited in intensity and duration by several elements built into the fiscal system which serve to moderate economic instability in an automatic and passive fashion. These so-called "automatic fiscal stabilizers" operate to bolster income flows to households and business firms in periods of declining output and, conversely, to slow down the growth of income in periods of expansion".

Also Council of Economic Advisers (1969: 72) stated that " By reducing the size of secondary effects on consumer and business outlays, these stabilizers reduce the severity of economic fluctuations. With the present tax system and schedules of unemployment compensation benefits, a decline in GNP automatically produces a 
reduction in government receipts and an increase in transfer payments. This limits the decline in private after-tax income-disposable personal income and retained corporate profits - to about 65 cents for each $\$ 1$ of reduction in GNP".

"In addition, automatic stabilizers work in a fashion that may inhibit the longrun expansion of demand. As the economy moves along the potential output path with reasonably stable prices, the Federal tax system generates an increase in revenues of about 6 percent a year. Unless this revenue growth is offset by reductions in taxes or by increases in expenditures, it acts as a "fiscal drag" by siphoning off income. Actions by the private sector can conceivably offset this effect if businesses increase investment expenditures faster than the growth of internal funds, or if households reduce their rate of saving. But under normal conditions, needed expansion may be prevented" (CoEA, 1969: 73).

It can not be said that the word "drag" reflects a positive situation in the word sense. There is a sense of slowing down the development of something or a situation or attracting them to unwanted directions.

According to Lee (2012: 179) "Fiscal drag is not a trivial issue, since fiscal drag is a sly way of extracting more tax from earners while avoiding headline increases in tax rates. Over time, people pay higher average and marginal tax rates and they don't really know why. And with these higher marginal rates come reduced work incentives, resulting in damaging effects on the economy".

Also Lee (2012: 180) noted that "In general, fiscal drag is the phenomenon appeared in the income tax. In addition, fiscal drag also occurs in other taxes where allowances fail to keep pace with underlying growth in the tax base. For instance, fiscal drag phenomenon can be seen, even on a smaller scale, for such taxes such as capital gain tax and stamp duty on properties, where the tax base tends to grow more quickly than the rise in thresholds".

Even inflation can cause the taxpayer pay more in real terms who do not enter in to the upper tax brackets, because it would erode the amounts in the tax tariff thresholds, tax exemptions and discounts in a progressive income tax. Therefore, progressivity of the tax system is damaged and proportionality of tax justice is hampered.

The thresholds in the tax tariffs are becoming more important than the tax rates for fiscal drag. In recent years, significant increases have been made in the number of taxpayers with the effort to distribute the tax in the base all over the world. However, due to the increase in the number of taxpayers, the ratio of taxpayers who pay taxes from the upper tax bracket also increased due to the fiscal drag. Tax administration can try to harmonize the tax system with inflation. However, the regulations to be made, for example, increasing the tax thresholds by inflation, may not be able to fully capture the future changes or may be delayed in time. In addition, the amounts that can be affected by inflation, such as tax exemptions and rebates, should also be considered.

As Thuronyi (1996: 437) states, "To understand adjustment for inflation, it is helpful to distinguish among three effects that inflation may have on real tax liability. 
These are (1) erosion of amounts expressed in national currency, (2) erosion of the value of tax obligations, and (3) other effects on the measurement of the tax base. The techniques for compensating for each of these effects are different... Every time a tax law contains an amount expressed in national currency, the value of this amount is eroded by inflation."

Inflation affects the structure of the tax system and can therefore change the realization levels of tax revenues. (Heinemann, 2001: 543) It is the erosion of the limits of the progressive income tax rates, most well-known and researched. If corrective adjustments are not made, an increasing tax rate will generate more real tax burden as nominal income increases (fiscal drag). Many countries have introduced automatic inflation adjustments to their tax systems. However, there is also a strong economic argument widely pushed for tax hikes related to fiscal drag. According to this view, increasing the real tax burden reduces consumption and thus collecting excess demand by acting as an automatic stabilizer to help cool the economy during the inflationary waves. However, this point of view focuses on the demand side, ignoring the impact that high tax burdens would have on production costs. If workers have bargaining power, real labor costs will increase and there will be an upward pressure on prices, which will increase the likelihood of a price spiral (Immervoll, 2006: 141).

For example, consider an individual who is subject to the average tax rate $\tau_{a}$ and the marginal tax rate $\tau_{m}$. If inflation is $\pi$, nominal gross wages $w$ should increase by $\Delta \mathrm{w}$. We can show this in the following equation;

$$
\frac{\Delta \omega}{w}=\frac{1-\tau_{\mathrm{a}}}{1-\tau_{\mathrm{m}}}
$$

According to this equation, if we consider an individual with pre-inflation wage $w=100$; then if $\tau_{a}=\% 30, \tau_{m}=\% 50$ and $\pi=\% 10$, the nominal wage of the individual will need to be increased by $\Delta w=14 \%$ in order to be kept at 70 , the first level of pretax gain. The higher the rate of progressivity in the tax base, the greater the additional tax burden caused by nominal wage increases, depending on inflation. Real wage costs will rise and prices will exert upward pressure, as wages will increase beyond inflation, even though real income after taxes before the inflation is not fully achieved. With total demand is lower because of higher taxes, an upward supply curve leads to a significantly lower output. As a result, if aggregate demand remains unchanged (despite increased public spending for example), the economy will see both low output and high prices (Immervoll, 2006: 144-145).

\section{Special Consumption Tax on Motor Vehicles in Turkey}

The most common areas where the concept of "fiscal liability" covering all financial obligations brought on the basis of public sovereignty is most likely to be applied are the automotive sector in general and the motor vehicles in particular. Because motor vehicles could not be excluded from the fiscal obligation. The reason for this is that the state does not lose any income related to taxes and other fiscal 
obligations due to tax security measures during the first acquisition, ownership and use of motor vehicles (Hacıköylü, 2017: 83).

Consumption taxes are among the top fiscal liabilities that generate the highest income for all countries. This is due not only to the expansion of the base of general consumption taxes such as value added tax but also to the fact that specific consumption taxes, including special consumption and supplementary consumption taxes, also play an important role in income collection and consumer behavior (Hacıköylü, 2017: 83).

Fiscal liabilities for motor vehicles in Turkish fiscal legislation, in particular the Turkish tax system, can be generally classified into three categories. These are about the acquisition, ownership and utilization of motor vehicles (Hacıköylü, 2017: 83).

Fiscal liabilities related to the acquisition of motor vehicles include all taxes, duties and other fiscal liabilities paid during the registration of a newly acquired vehicle, irrespective of whether the vehicle is new or used, and taken at once. The fiscal obligations of vehicles in the Turkish fiscal legislation are differentiated according to whether the vehicle is new (unused) or used (registered / second hand). Fiscal liabilities to be incurred if the motor vehicle subject to fiscal liability is new are; customs tax on the origin of the vehicle, special consumption tax, value added tax, and other fiscal obligations related to the registration (Valuable Documents Act etc.). If the vehicle has been used previously or has been previously registered, in other words a second hand, in this case, the seller pays value added tax according to the status of having a real or a legal personality. On the other hand, the notary fee paid to the notary public in the course of having ownership of the vehicle, irrespective of who the buyers are, is also included in the scope of the fiscal liability. Only the motor vehicle tax is included in the concept of fiscal liability related to the ownership of motor vehicles. Only the motor vehicle tax is included in the concept of fiscal liability related to the ownership of motor vehicles. Motor vehicle tax is collected periodically throughout the year and period of ownership (Hacıköylü, 2017: 84).

Financial liabilities related to the utilization of motor vehicles include; additional charges on the fuel cost, highway, bridge and tunnel tolls and the value added tax included in these fees, the obligatory fiscal liability insurance of the motor vehicle and the bank and insurance treatments tax which are included in the insurance costs of the insurance, vehicle inspection fees and exhaust inspection fees which are obligatory to be carried out at certain times (Hacıköylü, 2017: 85).

Motor vehicles should be taxed both in the country in which they are registered and in the country in which they are used (on the territory of the country or on the basis of citizenship). Acquisition and periodic ownership taxes on motor vehicles are normally levied in the country in which they are registered. However, fiscal obligations related to the use are applied wherever the vehicle is being used. However, unlike many other incidents, fiscal liability differences for motor vehicles do not usually lead to cross-border trade. This is because it is necessary to register in the countries where the single register number of motor vehicles is used and in most countries severe punishments are applied to such tax losses (Hacıköylü, 2017: 86). 
As of January 2017, the total number of motor vehicles registered to traffic is 21.211.701 in Turkey (TUIK, 2017). Especially due to the high number of motor vehicles and increasing demand for them causes motor vehicles to be taxed as an important taxation source. The fact that the high-income segment consumers constitutes a large proportion of motor vehicle purchases and these vehicles are also considered to be a component of the personal wealth, shows the importance of taxation to ensure a fair distribution of income (Demir, 2013: 15).

In addition, the necessity of taxation of vehicles due to the environmental damage caused by the use of motor vehicles also arises as a social purpose. Furthermore, the decrease in the amount of motor vehicle tax as the age of vehicles increase causes the vehicles that have filled their economic life to remain in traffic (Taraktaş, 2014: 467).

Especially the special consumption tax on motor vehicles is important for economic purpose as well as for fiscal purposes. Table 3.1 presents the share of special consumption tax on motor vehicles and motor vehicles tax revenues in general budget tax revenues for 2014, 2015 and 2016 (Hacıköylü, 2017: 89).

Table 1.1: Share of Special Consumption Tax on Motor Vehicles and Motor Vehicles Tax in General Budget Tax Revenues (\%)

\begin{tabular}{|l|c|c|c|}
\hline & 2014 & 2015 & 2016 \\
\hline Motor Vehicles Tax & 1,95 & 1,93 & 1,89 \\
\hline $\begin{array}{l}\text { Special Consumption Tax on } \\
\text { Motor Vehicles }\end{array}$ & 3,20 & 3,66 & 3,57 \\
\hline
\end{tabular}

Source: General Budget Cumulative Tax Revenues Collection Results are calculated from the Annual Activity Statement Report for 2015/2016 of the Revenue Administration Authority.

As can be seen from Table 3.1, it is seen that the share of the motor vehicles tax taken from ownership motor vehicles is about 1,90\% in the total tax revenues of 2014 , 2015 and 2016. When we look at the data of special consumption tax on the motor vehicles that constitute the list of (II) in the Goods and Services Taxes, it is seen that the share in the total tax revenues is $3,5 \%$ on average. While the total of the tax revenues of the year 2016 was 529.263.765.000 TL, the amount of the special consumption tax received from the motor vehicles in the same period was 18.938.472.000 TL. The value added tax for the purchase of motor vehicles is not included in the table. This is because in the statistics on taxes published in Turkey, the value-added tax is subjected to a separation only in the form of tax taken in imports and taken domestic, and no specific statistics on motor vehicles are published. The share of value-added tax received in 2016 was 31,8\% in total tax revenues, including $14,5 \%$ in imports. As a result, there is a wide range of fiscal obligations related to the acquisition, ownership and utilization of motor vehicles, but for statistical purposes only the net income from special consumption tax on motor vehicles and motor 
vehicles tax is known and statistical information on other fiscal obligations is not available in Turkey (Hacıköylü, 2017: 89).

Consumption taxes show a dual structure as value added tax and similar general consumption taxes taken on all goods and services and special consumption taxes that are taken only on certain goods and services. In the world practice, it is observed that general consumption tax as well as the said special consumption taxes have become increasingly important in terms of revenue collection and ability to influence the spending patterns of consumers and they begin to hold a prominent place in total tax revenue collections. With well-designed special consumption taxes, a wide range of consumers' preferences can be influenced from energy savings to transportation and the environment as well as provision of fiscal objectives (Hacıköylü, 2017: 91).

In Turkey, with 1985 reforms in the field of general consumption tax, 8 indirect taxes were abolished from the enforcement and value added tax was introduced. After reform, the second reform on indirect taxes is made by special consumption tax application. With the application of special consumption tax, it is aimed to simplify the existing complex structure of taxation of the certain goods and to contribute to the voluntary compliance of the taxpayers with the help of the simplified system on the other hand. 16 tax, duties and fund shares are abolished by this reform, which envisages a serious simplification in the area of indirect taxation (GiB, 2002).

\section{Recent Regulations in the Special Consumption Tax and Fiscal Drag}

Special consumption tax, which is single-stage, high-yielding and effective in the implementation of fiscal and social policies, is a newer tax than other taxes in the Turkish tax system. Indeed, the Council of Ministers can implement effective fiscal policies with respect to groups of goods and sectors covered by this tax by changing the tax rates and amounts of the special consumption tax within the jurisdiction specified in its code. One of the groups of goods that are subject to effective fiscal policies through special consumption tax is the motor vehicles and automotive sector on the list (II) attached to the Special Consumption Tax Law. This group of goods and therefore the sector is regulated almost every year. The latest arrangement was made in November 2016 (Hacıköylü, 2017: 92).

Vehicles listed in the list (II) attached to the Law on Special Consumption Tax; which are subject to registration in the acquisition stage and which are not subject to registration in the production stage, are subject to special consumption tax. The tax base of the special consumption tax is composed of the components of the value added tax base excluding the special consumption tax to be calculated in the first acquisition of the vehicles. One of the issues that cause constant debate about the special consumption tax is the higher tax rates. A number of amendments were made to the rates of special consumption tax applied to passenger cars listed in the list (II) by the decision of the Council of Ministers dated 24.11.2016 and numbered 2016/9542. In the Turkish automotive market, different special consumption tax rates are applied in three categories according to the engine cylinder volume of the vehicles in the Turkish 
automotive market, while the specific consumption tax rates applied to passenger cars are further elaborated by classifying the vehicles according to pre-tax prices within the relevant categories. According to this, the rates of the tax varies between $45 \%$ and $160 \%$ compared to the pre-tax price as well as the engine cylinder volume. As a result, the pre-tax price related to the determination of the special consumption tax base of the passenger cars has become very important (Hacıköylü, 2017: 92-93).

When considered in the framework of the application based on the Decree No. 2016/9542 published in the Official Gazette dated 25.11.2016 which is based on the price criterion in the special consumption tax, the pre-tax amount and therefore the special consumption tax base became very important. Special consumption tax base is even more important in terms of imported motor vehicles. Because, in the foreign currency purchase of vehicles, the purchase price is determined by converting the purchase price to the Turkish Lira at the purchase date foreign exchange buying rate of the Central Bank. In the case of a sale price lower than the purchase price of the vehicle carried at the current exchange rate, the tax value of the special consumption tax can not be lower than the amount constituting the value of the purchase price at the date of purchase and the value added tax on import (Hacıköylü, 2017: 105).

The invoicing of the vehicles acquired for sale at the new resale price (low price from initial sale) is seen by tax administration as an application in which the franchisees reduce the purchase price. The important point in the special consumption tax is the correct determination of the tax base. In the sale of imported motor vehicles, the sale price constitute the special consumption tax base. This tax base can be formulated as follows; (Hacıköylü, 2017: 106)

$=(\mathrm{FOB})$

(+) Overseas Shipping

(+) Insurance

(+) Overseas Loading and Handling Expenses

$=(\mathrm{CIF})$

(+) Excluding Taxes, Excise Taxes, Fees, Funds etc.

(+) Domestic Expenses (Expenses Before Registration)

= SCT Basis / VAT Basis (Amount Including Special Consumption Tax)

As can be understood from this formula, the special consumption tax and the value added tax of the imported motor vehicle are located on the same base. Therefore, a small amount of corrosion that might take place will affect both taxes. The special consumption tax is first calculated from the tax base found according to the elements forming the base of the value added tax. The sum of the special consumption tax amount and the special consumption tax base shall be the tax base of the value added tax and the value added tax shall be calculated from this tax base. This situation is criticized in the public opinion as "receiving tax from the tax" (Hacıköylü, 2017: 107). 
The tax rates of the motor vehicles listed in the "Other" line of motor vehicles listed at 87.03 G.T.i.P. in the list (II) attached to the Law on Special Consumption Tax have been amended with the Annex of Decision no. 2016/9542 and dated 25.11.2016. According to this; (Hacıköylü, 2017: 110)

Table 1.2: Number (II) List Tax Ratios

\begin{tabular}{|c|c|c|}
\hline G.T.i.P No & Goods & \multirow[t]{2}{*}{ Tax rate $(\%)$} \\
\hline \multirow{18}{*}{87.03} & -Others & \\
\hline & Engine cylinder volume not exceeding $1.600 \mathrm{~cm}^{3}$ & 60 \\
\hline & - SCT base do not exceed $40.000 \mathrm{TL}$ & 45 \\
\hline & $\begin{array}{l}\text { - SCT base exceeding } 40.000 \mathrm{TL} \text { and not exceeding } \\
70.000 \mathrm{TL}\end{array}$ & 50 \\
\hline & $\begin{array}{l}\text { Engine cylinder volume exceeding } 1.600 \mathrm{~cm}^{3} \text { and not } \\
\text { exceeding } 2.000 \mathrm{~cm}^{3}\end{array}$ & \\
\hline & - SCT base do not exceed $100.000 \mathrm{TL}$ & 100 \\
\hline & $\begin{array}{l}\text {-Which have electric motor power exceeding } 50 \mathrm{KW} \\
\text { and motor cylinder volume not exceeding } 1800 \mathrm{~cm}^{3}\end{array}$ & 60 \\
\hline & -- SCT base do not exceed $50.000 \mathrm{TL}$ & 45 \\
\hline & $\begin{array}{l}\text {-- SCT base exceeding } 50.000 \mathrm{TL} \text { and not exceeding } \\
80.000 \mathrm{TL}\end{array}$ & 50 \\
\hline & - Others & 110 \\
\hline & Engine cylinder volume exceeding $2.000 \mathrm{~cm}^{3}$ & \\
\hline & $\begin{array}{l}\text { Which have electric motor power exceeding } 100 \mathrm{KW} \\
\text { and motor cylinder volume not exceeding } 2.500 \mathrm{~cm}^{3}\end{array}$ & 110 \\
\hline & $\begin{array}{l}\text { Which have electric motor power exceeding } 100 \mathrm{KW} \text {, } \\
\text { motor cylinder volume is between } 2.000 \mathrm{~cm}^{3}-2500 \\
\mathrm{~cm}^{3} \text { and SCT base do not exceed } 100.000 \mathrm{TL}\end{array}$ & 100 \\
\hline & - Others & 160 \\
\hline & Electric motor only & \\
\hline & -Engine power not exceeding $85 \mathrm{~kW}$ & 3 \\
\hline & $\begin{array}{l}\text {-Engine power exceeding } 85 \mathrm{~kW} \text { but not exceeding } \\
120 \mathrm{~kW}\end{array}$ & 7 \\
\hline & -Engine power exceeding $120 \mathrm{~kW}$ & 15 \\
\hline
\end{tabular}

Source: Decree No. 2016/9542 published in the Official Gazette dated 25.11.2016

As seen in the above list, the rates of special consumption tax to be applied to listed motor vehicles vary according to the motor and electric power of the vehicle as well as the specific consumption tax base (Hacıköylü, 2017: 112).

Adjustments were made in the special consumption tax on 25.11.2016 in accordance with the decree published in the Official Gazette. In a study (Pişkin, 2017a) 
conducted for this regulation it is stated that, before the changes introduced by this regulation in the Turkish automotive market, different special consumption tax rates are applied in three categories according to the engine volume of motor vehicles. With this regulation, within the relevant categories, the rates of special consumption tax applied to these vehicles are also detailed by classifying them according to the pre-tax price of motor vehicles. The mentioned study included the following calculations about the subject; (Hacıköylü, 2017: 112).

Graphic 1.1: Changes in the SCT, Selling Price and the Total Tax Burden of the Automobiles According to Pre-Tax Price (PTP) and the Engine Cylinder Volume (ECV) Groups (1: ECV < $1.600 \mathrm{~cm}^{3} ; 2: 1.600 \mathrm{~cm} 3<\mathrm{ECV}<2.000 \mathrm{~cm}^{3} ; 3: 2.000 \mathrm{~cm}^{3}<\mathrm{ECV}$ ).

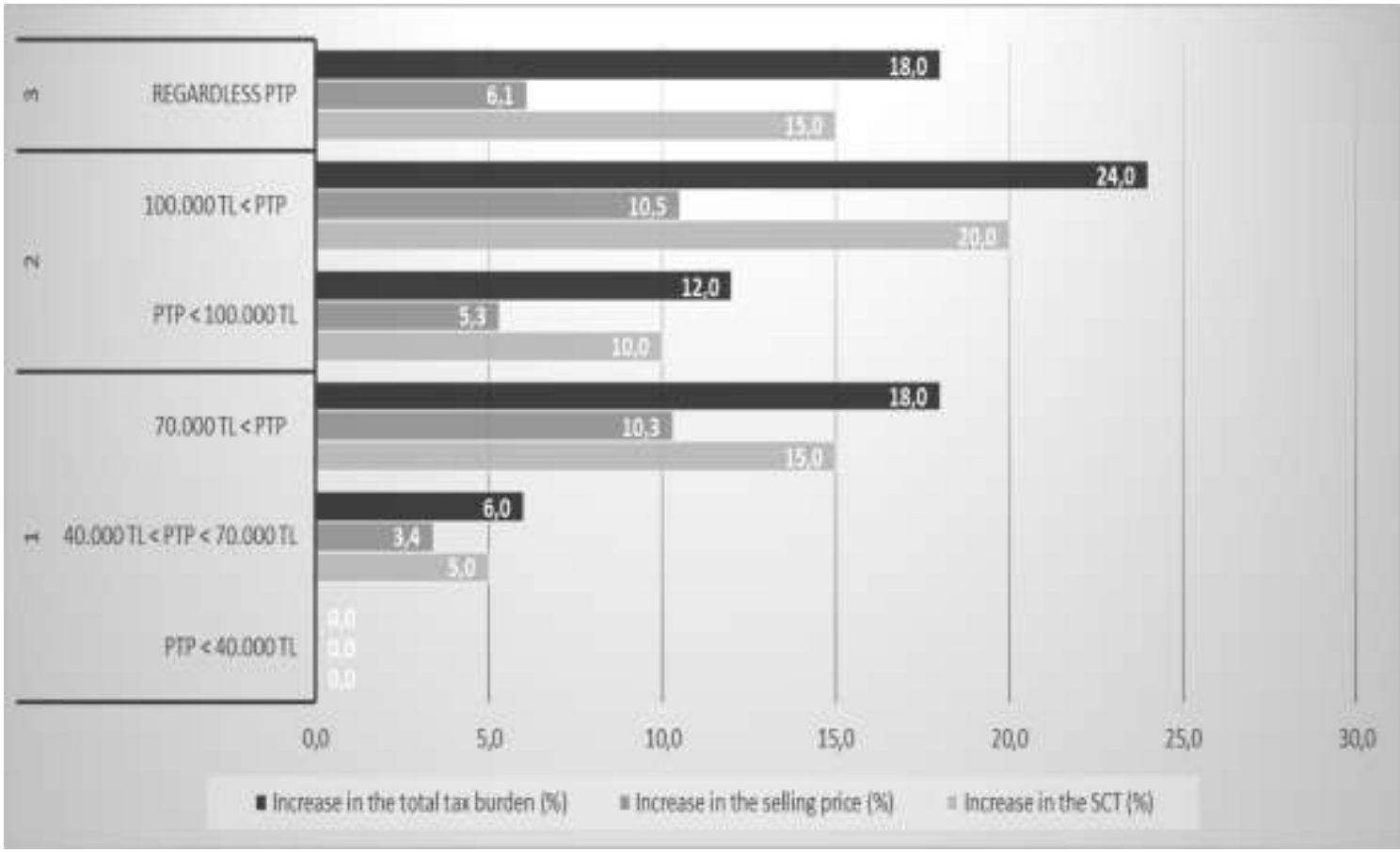

There was no change in the $45 \%$ special consumption tax applied to automobiles that did not exceed the pre-tax price of $40.000 \mathrm{TL}$, so there was no change in the final sales price and total tax burden of these vehicles (Pişkin, 2017a: 61).

Raising the rate of special consumption tax applied to automobiles whose pretax price exceeds $40.000 \mathrm{TL}$ and do not exceed $70.000 \mathrm{TL}$ caused a 3,4\% increase in the selling price of vehicles and the total tax burden resulting from the inclusion of value added tax of vehicles entering the group to increase by 6 points to 77\% (Pişkin, 2017a: 61).

The group that was most affected by the new special consumption tax regulation was automobiles whose pre-tax price exceeded $70.000 \mathrm{TL}$. The increase in the special consumption tax rate from $45 \%$ to $60 \%$ in the relevant price range caused the total tax burden of vehicles entering the group to increase by 18 points to $89 \%$ and the final price to increase by 10,3\% (Pişkin, 2017a: 61). 
The rate of special consumption tax applied to automobiles whose engine cylinder volume is between $1.600 \mathrm{~cm}^{3}$ and $2.000 \mathrm{~cm}^{3}$ and whose pre-tax price does not exceed 100.000 TL has increased from 90 to $100 \%$. Depending on the specific consumption tax rate, the total tax burden of the vehicles entering the related cylinder volume and price group increased by 12 points to $136 \%$, while the final vehicle price increased by 5,3\% (Pişkin, 2017a: 61).

The rate of special consumption tax applied to automobiles whose engine cylinder volume is between $1.600 \mathrm{~cm}^{3}$ and $2.000 \mathrm{~cm}^{3}$ and whose pre-tax price exceeds 100.000 TL has been increased from $90 \%$ to $110 \%$. Accordingly, the total tax burden of the vehicles in this group increased by 24 points to $148 \%$, while the final vehicle price rose by $10,5 \%$ (Pişkin, 2017a: 61 ).

Finally, the rate of special consumption tax applied to automobiles with an engine cylinder volume of $2.001 \mathrm{~cm}^{3}$ or more has been increased from $145 \%$ to $160 \%$ regardless of the pre-tax price of the vehicle. As a result, the total tax burden of vehicles with the relevant engine cylinder volume increased by 18 points to $207 \%$, while the prices of motor vehicles increased by 6,1\% (Pişkin, 2017a: 62).

Special consumption tax from the first acquisition of motor vehicles is an important fiscal obligation for motor vehicles. One of the constant debate issues about the special consumption tax is the taking of the value added tax over the special consumption tax, in other words, the amount of the special consumption tax calculated in the value added tax base. This is the case where tax is levied on the tax. Although, in the related article of the Value Added Tax Law, there is legal regulation on this issue, this situation causes taxpayers to take a negative attitude towards the taxation. As a result, the problem of voluntary participation of the tax, which is one of the problems experienced in the Turkish tax system, is emerging. If this form of calculation, which is appropriate for fiscal purposes, is abandoned, there may be a certain amount of tax loss. However, the socio-psychological impact of abolishing this regulation, which is a constant debate among taxpayers in the public opinion and which could also prevent voluntary participation, may be more favorable. It may also be regarded as an incentive for the sector, since there will be a slight decrease in the prices of motor vehicles if this practice is abandoned (Hacıköylü, 2017: 166).

KPMG Turkey Automotive Managers Research - 4, which was organized by KPMG Turkey in 2016, which provides inspection, tax and consultancy services, revealed that the special consumption tax on the first acquisition of motor vehicles is an important fiscal obligation for motor vehicles (KPMG, 2016). It has been stated that in the study conducted, for the next five years in the automotive market one of the factors that will affect the growth of the market is the tax burden, especially the special consumption tax on the sector.

It can be said that the economic objective of taxation is taken as the basis at the most of the arrangements made in recent years in the current tax system in Turkey, especially with respect to motor vehicles. The increase in demand, especially for imported automobiles, has increased the need for interventions that will be realized with tax policies in this area (Saygın, 2013: 182). In other words, the demand 
for imported motor vehicles (especially passenger cars) in Turkey is increasing, the tax interventions are also increasing and the tax rates, especially the special consumption tax, are also increasing. However, what is important here is that the demand for imported motor vehicles has fallen or not as a result (Hacıköylü, 2017: 167).

This issue was addressed in a study conducted at the beginning of 2017. Accordingly, it was observed that the total automobile market responded statistically significant and negatively to the increases in special consumption tax. However, vehicles with an engine cylinder volume less than $1.600 \mathrm{~cm}^{3}$, which accounts for $96 \%$ of the automobile market, responded to the shock of special consumption tax negatively like the total automobile market but the duration of the reaction was limited to 9 months. The response of special consumption tax rate applied to vehicles with cylinder volume of $1.601 \mathrm{~cm}^{3}-2.000 \mathrm{~cm}^{3}$ was found to be statistically significant and negative for 24 months, and it has been found that there is an increasing narrowing effect. The response of an increase in the rate of special consumption tax applied to vehicles with engine cylinder volumes greater than $2.000 \mathrm{~cm}^{3}$ was statistically significant and negative for only 5 months and and the effect was weaker than the sales of other automobiles (Pişkin, 2017b: 16).

As can be seen in the study made, the contraction effect of the increase in special consumption tax on motor vehicles in Turkey is maximum on vehicles with $1.600 \mathrm{~cm}^{3}-2.000 \mathrm{~cm}^{3}$ engine cylinder volume, while the least impact is on vehicles with engine cylinder volume greater than $2.000 \mathrm{~cm}^{3}$. In Turkey, on vehicles that are less than $1.600 \mathrm{~cm}^{3}$ (96.35\% of the motor vehicles sold by the end of December 2016), increase of special consumption tax have a narrowing effect for 9 months. It should be noted, however, that the above-mentioned work is based on the restrictive effects determined by the increases in the rates of special consumption tax on motor vehicles before 2016. With the regulation at the end of November 2016 which takes in consideration of the pre-tax amount of the vehicle as well as the engine cylinder volumes in the calculation of the special consumption tax, may have a different effect on the vehicle sales (Hacıköylü, 2017: 168). For example, according to March 2017 data, automobile and light commercial vehicle sales decreased by $11,03 \%$ compared to the previous year. By the end of March 2017, car sales decreased by 9,5\% for vehicles with engine cylinder volume less than $1.600 \mathrm{~cm}^{3}, 8,9 \%$ for vehicles with engine cylinder volume between $1.600 \mathrm{~cm}^{3}$ and $2.000 \mathrm{~cm}^{3}$, and $45,7 \%$ for vehicles with $2.000 \mathrm{~cm}^{3}$ engine cylinder capacity (OYDER, 2017).

With the special consumption tax regulation at the end of November 2016 which broughts price criterion in addition to the engine cylinder volume and age criteria framework, the pre-tax amount has gained considerable importance in terms of determining the amount of the tax. However, even if the companies in the sector don't increase prices for passenger cars, the pre-tax price in connection with the exchange rate may decrease or increase and the amount of tax to be paid may change periodically. In this case, customers are reported by the company in the form of a statement like, "... The price difference caused by the increasing rates of special consumption tax which is determined on the price list (which are calculated on the 
basis of the value added tax which changes with the exchange rates during the import phase of the vehicle) will be covered by the customer " (Hacıköylü, 2017: 168-169).

Vehicles in the same engine cylinder volume group but which are close to an upper price threshold in terms of price classifications (price of 40.000 TL and 70.000 TL for vehicles with engine cylinder volume less than $1.600 \mathrm{~cm}^{3}$, and $100.000 \mathrm{TL}$ for vehicles with engine cylinder volume between $1600 \mathrm{~cm}^{3}-2000 \mathrm{~cm}^{3}$ ) are in the group, which will be adversely affected by the increase in exchange rates in the short-term (Pişkin, 2017b: 62). This situation actually brings up a problem. Automakers can keep the pre-tax amount of the vehicle low so as not to be adversely affected by the increase in the exchange rate and therefore not to exceed a higher special consumption tax rate. This situation can be done in agreement with the distributor company, or it can be in the form of importing and upgrading the base model vehicles after sales, which will be abrasive for the special consumption tax and value-added tax bases, under the assumption that in both cases it does not reflect the truth (Hacıköylü, 2017: 169).

After the base model vehicle is imported and the vehicle is sold, the special consumption tax base can be eroded by adding the parts imported as spare parts. For example, in agreement with the buyer, amounts relating to retrofitting features such as navigation, rain sensor and parking sensor are not added to the invoice to be arranged for the car, then a different invoice can be issued for these features by the seller (or authorized service). In this way, these spare parts are not taxed in special consumption tax because they do not enter into the issue of that tax (Gülçiçek, 2012: 92).

A tax reduction is not foreseen in the sector for incentive purposes for motor vehicles except for electric vehicles and when looking at past applications except for the reduction of special consumption tax rates only to temporarily revive the sector during crisis periods, the tax rates generally have an upward trend (Gülçiçek, 2013: 26).

Indeed, especially with the recent special consumption tax regulation, there is a serious tax advantage in electric motor vehicles compared to gasoline / diesel motor vehicles. Tax rates are between $3 \%$ and $15 \%$ for only electric powered motor vehicles numbered 8703 G.T.I.P. in the list (II) attached to the Special Consumption Tax Law. However, the tax rate of 8703 G.T.I.P numbered hybrid vehicles with electric motor ranges from $60 \%$ to $100 \%$ in petrol and from $45 \%$ to $160 \%$ in diesel vehicles. On the other hand, for the vehicles in the attached list of (II) numbered 8704 G.T.I.P. there is no difference in terms of tax rate between electric and diesel / gasoline vehicles. The ratio of the specific consumption tax applied to those 8704 G.T.I.P. numbered vehicles used for transport of goods and not exceeding $3.000 \mathrm{~cm}^{3}$ is the same as that applied only to those that are electric and do not exceed $85 \mathrm{~kW}$ of engine power. The legislator therefore provides a tax advantage for electric and hybrid motor vehicles, especially for passenger cars, but does not provide the same advantage for commercial vehicles. If the purpose is to promote electric and / or hybrid motor vehicles, this advantage must be achieved for both vehicle classes (Hacıköylü, 2017: 170). 


\section{Conclusion}

The automotive sector in Turkey is very important both for the public and consumers. For consumers, the prospect is that the purchase of motor vehicles is perhaps the largest expenditure item after the purchase of the property, within the expenditures they have made for life. In terms of the public sector, the automotive sector is an important sector in terms of public revenues as well as important in terms of exports.

Certainly, taxpayers have been subject to fiscal drag as a result of movements that may occur in exchange rates and / or prices of motor vehicles with the Decree No. 2016/9542 published in the Official Gazette dated 25.11.2016 which is based on the price criterion in the special consumption tax. This has caused a serious drop in demand for automobiles. However, the level of car ownership in Turkey is low compared to other European countries and the demand for automobiles is alive. This could lead to tax abatement effects by causing individuals to buy low-specs vehicles to keep special consumption tax base low. However, the identification of long-term increases in demand for automobiles in recent studies shows that being exposed to fiscal drag for employees who want to buy cars, can cause high wage demands, which has an impact on the economy's supply footing, and cause overall prices increase. This situation may wipe out the automatic stability expectation of the law maker and tax administration.

However, in the calculation of the tax amount, the fact that energy and environmental factors are not taken into account is often the cause of debate. Taxes on motor vehicles are related to the energy politics of the countries. Providing tax incentives for fuel-efficient vehicles in motor vehicle tax may reduce energy expenditure. This will also encourage the protection of the environment.

While fiscal liabilities for motor vehicles are an important source of income in many countries, in fiscal policy evaluations, this issue is taken into account with equal importance to other policy areas such as transportation - energy - environment. Transport may therefore require that the total tax burden on heavy commercial vehicles be reasonably low in order to promote trade policies and commercial activities, or the taxation of motor vehicles may be designed to direct transport from road to rail or from public to private transport. Energy and environmental policies may also require high tax rates for motor vehicles to control consumer behaviors in order to save energy and reduce pollution.

Higher taxes on motor vehicles will probably limit the number of motor vehicles on the roads. Nevertheless, at first glance this may seem like a preference for environmental policies, but constantly high taxation of a new vehicle acquisition will increase the number of old vehicles polluting the atmosphere. In this case, old, unsecured, fuel-consuming and environmentally polluting vehicles will continue to be used. In some countries, short-term incentives are given for the withdrawal of such old vehicles from the market. One example to such incentives is the practice in Turkey called "scrap incentive". 
Taxation is a deterrent which influence real and legal persons decisions and preferences. For this reason, it is not right to look at taxation only as means of generating income. Taxation also helps to spread the applied social policy throughout society. It is one of the main footholds in the implementation of environmental and social policies in particular. The classic purpose of taxation is called fiscal purpose which refers to the financing of public expenditures required by public services. It is desirable to achieve economic and social goals as well as fiscal objectives in taxation. As a matter of fact, while economic, social and demographic purposes are mostly in front of the fiscal purpose in wealth taxation, particularly in indirect taxes such as value added tax and special consumption tax, economic and fiscal purposes take the foreground. In the Turkish tax system, it can be said that the recent regimes in terms of taxes on motor vehicles and especially automobiles serve for economic purposes. Recently increasing demand for imported automobiles in Turkey, necessitates interventions to be implemented with tax policies in this area. Although environmental factors are not taken into account in the motor vehicle tax on the motor vehicles in the Turkish tax system, environmental factors, especially in EU countries, are considered as an important factor in taxation, especially for reducing $\mathrm{CO}_{2}$ emissions.

In the motor vehicle tax applied in Turkey, the common criterion for all motor vehicles, the decrease in the amount of the payable tax as the age increases, is the most important proof that the environmental factor is not taken into consideration. Existing motor vehicles taxation in which only engine volume and age of vehicle are taken into consideration, can lead to negative results to environmental objectives. As the age of motor vehicles increases, they may be subject to more taxation because they will cause more $\mathrm{CO}_{2}$ emissions to the environment. In the current tariff, vehicles with the same engine volume but with different $\mathrm{CO}_{2}$ emissions are taxed the same rate. Low emissions vehicle use is not encouraged. Another important issue in terms of $\mathrm{CO}_{2}$ emissions is the age of vehicles in traffic. Because the age of vehicles in traffic is one of the important determinants of emissions. In fact, the idea that vehicles pollute the environment more as they age, is a problem that can be solved at some point. So that the emission controls can be done more often as the age of the vehicle increases. For example, in motorized vehicles of 10 years and older, this control can be done annually, which will remove the harm that older vehicles can give to the environment. In public vehicles, the meticulous application of emission controls can also be considered as a measure to be taken in this area. In terms of motor vehicles tax, the most effective means of combating $\mathrm{CO}_{2}$ emissions is the adoption of taxation by taking in the account of the potential $\mathrm{CO}_{2}$ emission values. In this context, the Council of Ministers, which has the authority to apply tax discounts of up to $50 \%$, use of this authority in vehicles using catalytic convectors according to EURO norms, so that the tax can also qualify for environmental taxation. It should be noted that at the end of 2016, in the special consumption tax, the Council of Ministers used this authority for similar points in electric motor vehicles. 


\section{References}

Creedy, J. and Gemmell, N. (2007). "Tax Revenues and Fiscal Drag: An Introduction", Australian Economic Review, 40: pp. 323-338.

Demir, M. A. (2013). Türkiye'de Motorlu Taşıtlar Vergilendirmesinin Analizi ve Değerlendirilmesi, Unpublished Master's Thesis, Gazi University S.B.E. Public Finance D. Supervisor: Doç. Dr. Fatih Saraçoğlu, Ankara.

Fatas, A. and Mihov, I. (2001). "Government Size and Automatic Stabilizers: International and Intranational Evidence", Journal of International Economics, 55: pp. 3-28.

GiB. (2002). General Rationale of Special Consumption Tax, Law No: 4760 Date: 06.06.2002. http://www.gib.gov.tr/fileadmin/mevzuatek/gerekceler/KDV/ tuk_4760_sayili_kanun.pdf. (10.03.2017)

Gülçiçek, A. (2012). Otomotiv Sektörünün ÖTV Düzenlemelerindeki Yeri ve Özelikli Hususlar. Vergi Sorunları Dergisi, 289, October

Gülçiçek, A. (2013) . Türkiye Otomotiv Sektörü Vergi Gelirlerine Etkisi ve Vergisel Sorunlar. Vergi Sorunları Dergisi. 300, September: pp. 21-26.

Hacıköylü, C. (2017). Türkiye'de Motorlu Kara Taşıtlarına iliş̧in Mali Yükümlülükler; Kavramlar, Uygulama ve Değerlendirmeler, 1. Baskı, Eskişehir, Nisan Kitabevi.

Heinemann, F. (2001). "After the death of inflation: will fiscal drag survive?", Fiscal Studies, 22(4), pp. 527-546.

Immervoll, H. (2006). "Fiscal Drag-An Automatic Stabiliser?", Volume 25 - MicroSimulation in Action, Ed. Bargain, O., Emerald Group Publishing Limited, pp. 141-163.

Immervoll, H. (2005). "Falling up the stairs: The effects of bracket creep on household incomes" Review of Income and Wealth, 151(1), pp. 37-62.

Kalkınma Bakanlığı. (2014). Otomotiv Sanayi Çalışma Grubu Raporu 2014-2018, Kalkınma Bakanlığı Yayın No: KB: 2890

KPMG, (2016). Türkiye Otomotiv Yöneticileri Araştırması - 4, https://home.kmpg.com (01.04.2017)

Lee, S. (2012). The Effect of Fiscal Drag on Tax Revenue and Tax Burden. Young Back Choi (Ed.) in Institutional Economics and National Competitiveness. New York: Routledge.

Oktar, K. (2008). Özel Tüketim Vergisi Yorum ve Açıklamaları, 1. Baskı, Ankara, Savaş Yayınevi.

OYDER, (2017). Automobile Authorized Dealers Association Announcement, http://ww.oyder_tr.org (03.04.2017) 
Pişkin, S. (2017a). Otomotiv Sektör Raporu, Türkiye Otomotiv Sanayi Rekabet Gücü ve Talep Dinamikleri Perspektifinde 2020 iç Pazar Beklentileri, Ocak 2017, TSKB, Ekonomik Araştırmalar, http://osd.org.tr/Sites/1/upload/files/ Otomotiv_Sektor_Raporu_TSKB-2208.pdf (02.04.2017)

Pişkin, S. (2017b). "Belirsizlik ve Bilinmezlik: Yeni ÖTV Düzenlemesinin Otomotiv Sektörüne Etkileri", http://osd.org.tr/Sites/1/upload/files/Otomotiv_Sektoru_ Bilgi_Notu_Yeni_OTV_Duzenlemesinin Otomotiv_Sektorune_Etkileri_TSKB2207.pdf (01.05.2017).

Saygın, Ö. (2013). Otomobiller Üzerinden Alınan Vergilerin Ampirik Analizi, Vergi Sorunları Dergisi, 296, May: pp. 180-190.

Taraktaş, A. (2014). Karbondioksit Emisyonlarının Azaltılması için Motorlu Taşıtların Vergilendirilmesi; Avrupa Birliği'ndeki Son Gelişmeler ve Türkiye için Öneriler, Yaklaşım Dergisi, 264, December: pp. 461-468.

Thuronyi, V. (1996). Adjusting Taxes for Inflation. Victor Thuronyi (Ed.) in Tax Law Design and Drafting. Washington: International Monetary Fund.

TÜiK. (2017). News Bulletin, No:24596, 10 March 2017, http://www.tuik.gov.tr (19.03.2017).

U.S. Council of Economic Advisers. (1969). Economic Report of the President 1969. Available at www.presidency.ucsb.edu/economic_reports/1969.pdf (01.05.2017). 